\title{
Comparative study of phenotypic and virulence properties in Vibrio vulnificus biotypes 1 and 2 obtained from a European eel farm experiencing mortalities
}

\author{
C. Amaro $^{1,2}$, E. G. Biosca ${ }^{1}$, C. Esteve ${ }^{1,2}$, B. Fouz ${ }^{2}$, A. E. Toranzo ${ }^{2}$ \\ ${ }^{1}$ Departamento de Microbiología, Universidad de Valencia, E-46100 Burjassot, Spain \\ ${ }^{2}$ Departamento de Microbiología y Parasitología, Universidad de Santiago de Compostela, E-15706, Spain
}

\begin{abstract}
Strains of Vibrio vulnificus biotype 2 were recovered from diseased European eels Anguilla anguilla during 2 epizootics. These strains were biochemically and serologically identical to the ATCC 33149 strain, which was isolated from the Japanese eel Anguilla japonica. The isolates of biotype 2 from European eels were more virulent for elvers $\left(L D_{50}<10^{2} \mathrm{cfu}\right.$ ) than the Japanese strain used as control $\left(\mathrm{LD}_{50}=10^{4} \mathrm{cfu}\right.$ ). All strains of biotype 2 were able to adhere to human and fish cell lines and were also strongly cytotoxic. The extracellular products (ECPs) of the Japanese strain exhibited lipolytic, phospholipolytic, proteolytic, and haemolytic activities, whereas the ECPs of the Spanish isolates displayed only proteolytic activity. Strains of biotype 1 were recovered from tank water and healthy eels during the second outbreak. These isolates were biochemically similar to the type strain ATCC 27562, and serologically distinct from the isolates of biotype 2. Strains of biotype 1 produced proteases, haemolysins, and cytotoxins and showed specific adhesion to human cells, but they were non-pathogenic for eels. The strains of biotype 2 were more virulent for mice $\left(L_{50}=10^{5}\right.$ to $\left.10^{6} \mathrm{cfu}\right)$ than the strains of biotype $1\left(L_{50}=10^{8} \mathrm{cfu}\right)$, suggesting that this eel pathogen may also represent a health hazard problem for fish farmers.
\end{abstract}

\section{INTRODUCTION}

Vibrio vulnificus biotype 2 was initially isolated as Vibrio sp. from diseased Japanese eels Anguilla japonica (Muroga et al. 1976a, b), and later it was classified as $V$. vulnificus biotype 2 by Tison et al. (1982). Biotype 1 of the species is associated with human infections (Blake et al. 1980), but it can also be recovered from water samples, especially from warm water, low salinity situations (Kelly 1982). Biotype 2 contains only pathogenic strains for eels.

We recently reported the first isolation of Vibrio vulnificus biotype 2 from an outbreak of diseased European eels Anguilla anguilla that were being cultured in brackish water in Valencia (Spain) (Biosca et al. 1991). The eels were treated with oxolinic acid until the outbreak was controlled, but a second outbreak occurred 2 mo later. During the latter outbreak, strains of $V$. vulnificus biotype 2 were recovered from the internal organs, and strains of biotype 1 were isolated from tank water and the gills of healthy eels

This paper describes the phenotypic and serological characterization of the isolates of both biotypes and compares the isolates with collection strains ATCC 27562 (biotype 1) and ATCC 33149 (biotype 2). Because Vibrio vulnificus biotype 1 has been described as a human pathogen, and $V$. vulnificus biotype 2 as an eel pathogen, we considered it worthwhile to evaluate the virulence of our biotypes for both eels and mice Finally, we investigated the production of exoenzymes, cytotoxins and adhesins using cell lines of poikilothermic and homoiothermic animals.

\section{MATERIALS AND METHODS}

Bacterial strains and characterization. The commercial miniaturized system API $20 \mathrm{E}$ was used for the presumptive identification of the tank-water and eel isolates. The isolates were also tested for 62 additional 
biochemical reactions that had been previously used to identify Vibrio vulnificus biotype 2 during the first outbreak. In addition, their sensitivity to 19 antimicrobial agents was determined (Biosca et al. 1991). The type strain of the species, ATCC 27562 of biotype 1, and one of the Japanese strains used by Tison et al. (1982) to define biotype 2 of $V$. vulnificus, were included in the study as reference cultures. Strains were kept as permanent cultures in a lyophilized form. Stock cultures were maintained in Marine Broth (Difco) plus $20 \%$ glycerol $(\mathrm{v} / \mathrm{v})$ at $-80^{\circ} \mathrm{C}$.

Serology. Formalin-killed whole cells of the Japanese strain (biotype 2 ATCC 33149) served as the antigen for rabbit immunization, and the resulting antiserum was obtained as described by Toranzo et al. (1987). Slide agglutination assays were conducted to examine the serological relationships among the Spanish isolates of both biotypes and the Japanese strain. The somatic ' $O$ ' antigen preparations, obtained by heating aliquots of the whole cell suspensions at $100^{\circ} \mathrm{C}$ for $1 \mathrm{~h}$, were used as antigens in the agglutination assays. Cross-quantitative agglutination tests were performed in microtitre wells containing serial 2 fold dilutions of $25 \mu \mathrm{l}$ aliquots of the antisera. Resulting titres represented the reciprocal of the highest dilution of an antiserum giving a positive reaction with the ' $O$ ' antigen after $12 \mathrm{~h}$ at $15^{\circ} \mathrm{C}$.

Virulence assays. The assays for pathogenicity were made on elvers ( 5 to $8 \mathrm{~g}$ ) and BALBc mice ( 6 to $8 \mathrm{wk}$ old) as described by Toranzo et al. (1983) and Wright et al. (1990), respectively. Fish were intraperitoneally inoculated with $0.1 \mathrm{ml}$ and mice with $0.2 \mathrm{ml}$ of 10 -fold dilutions of each bacterial strain in PBS (phosphatebuffered $1 \% \mathrm{NaCl}, \mathrm{pH} 7.0$ ). Six fish and 4 mice were injected per bacterial dose, including 2 sets of animals inoculated with sterile PBS as negative controls. Mortalities were recorded during a $7 \mathrm{~d}$ period. Elvers were considered to have died of the challenge only when the injected bacteria were reisolated as pure cultures from kidney or liver of moribund elvers. The virulence $\left(L D_{50}\right)$ was calculated by the Reed \& Muench method (1938).

Exoenzymatic, haemolytic, and cytotoxic activites of ECPs. Strains were cultured on tryptic soy agar (TSA) plates at $25^{\circ} \mathrm{C}$ for $24 \mathrm{~h}$ and their extracellular products (ECPs) were obtained as previously described (Liu 1957). Protein concentration of the ECPS was determined by the method of Bradford (1976) with the Bio-Rad reagent (Bio-Rad Laboratories, Munich). Proteolytic, lipolytic, phospholipolytic, and haemolytic activities were evaluated on Agarose plates $10.8 \%$ (w/v) Agarose (Oxoid) in PBS, pH 7.0) containing one of the following substrates: $2 \%(\mathrm{w} / \mathrm{v})$ skim milk (Difco), $3 \%(w / v)$ gelatin (Oxoid), $5 \%(v / v)$ Tween 80 , $5 \%(\mathrm{v} / \mathrm{v})$ egg-yolk emulsion (DifCo) or $5 \%(\mathrm{v} / \mathrm{v})$ sheep erythrocytes. A $5 \mu \mathrm{l}$ aliquot of each ECP sample was inoculated in wells of 2 to $3 \mathrm{~mm}$ diameter made in these plates. The diameter of the reaction zone around the inoculated well in duplicate experiments served as a relative quantification of the hydrolytic activities. Cytotoxicity assays were determined on fish and human cell lines as described by Toranzo et al. (1983). CHSE-214 (chinook salmon embryo), RTG-2 (rainbow trout gonad), EPC (epithelioma papillosum of carp) and HELA (human cervix epithelioid carcinoma) cell monolayers were inoculated with $0.1 \mathrm{ml}$ of serial dilutions of each ECP. Total or partial destruction of monolayers within a $24 \mathrm{~h}$ period was scored as a positive cytotoxic effect. Trypan-blue staining was used to assess the effect of the ECPs on cell viability. To evaluate the effect of heating on cytotoxic activity, the most sensitive cells were inoculated with ECPs previously heated at $80^{\circ} \mathrm{C}$ for $15 \mathrm{~min}$

Adhesion to cell lines. The ability of the isolates to adhere to fish cell lines was assayed on RTG-2 and HELA cells as described by Santos et al. (1990). Briefly, cells were grown as monolayers in 24-well culture plates with Eagle's minimum essential medium (MEM) plus $5 \%$ fetal calf serum and $50 \mu \mathrm{g} \mathrm{ml}^{-1}$ gentamycin. Two hours before the test, the medium was replaced with fresh MEM without antibiotics. Wells containing cell. monolayers were rinsed with PBS, treated with Carnoy's fixative (20 min), and washed with PBS. One $\mathrm{ml}$ of bacterial suspension in PBS $\left(10^{8}\right.$ cells $\left.\mathrm{ml}^{-1}\right)$ was added to the fixed cells, and plates were incubated for $1 \mathrm{~h}$ and washed with PBS. Plates were treated again with Carnoy's fixative (20 min), stained with Giemsa ( $5 \mathrm{~min}$ ), and examined for bacterial adherence using an inverted microscope.

\section{RESULTS AND DISCUSSION}

\section{Biochemical characteristics}

Ten strains of presumptive Vibrio vulnificus were isolated as pure cultures from the kidneys and livers of diseased eels during a disease outbreak in an eel farm located near Valencia. The infectious disease, with clinical signs suggestive of vibriosis, was similar to one that had been observed on the same farm 2 mo before (Biosca et al. 1991). Presumptive V. vulnificus strains, identified by using the API $20 \mathrm{E}$ system, were also recovered from tank water and gills of healthy eels on the farm. According to the 62 biochemical tests used to characterize Vibrio isolates (Biosca et al. 1991), all strains were unequivocally identified as $V$. vulnificus. The bacteria isolated from diseased eels during the second epizootic exhibited the same morphological and biochemical characteristics as the ones isolated 
Table 1 Vibrio vulnificus. Phenotypic characteristics differentiating biotypes 1 and 2

\begin{tabular}{|c|c|c|c|c|c|}
\hline \multirow[t]{2}{*}{ Characteristic } & \multirow[t]{2}{*}{ Strains from: } & \multicolumn{2}{|c|}{ Spanish fish farm } & \multicolumn{2}{|c|}{ Culture collection } \\
\hline & & Biotype $2(10)^{\text {के }}$ & Biotype $1(3)^{b}$ & $\begin{array}{c}\text { ATCC } 33149 \\
\text { (Biotype 2) }\end{array}$ & $\begin{array}{c}\text { ATCC } 27562 \\
\text { (Biotype 1) }\end{array}$ \\
\hline O/129 sensituvity: & $\begin{array}{l}10 \mu \mathrm{M} \\
150 \mu \mathrm{M}\end{array}$ & $\begin{array}{l}+ \\
+\end{array}$ & $\begin{array}{l}(33) \\
(33)\end{array}$ & $\begin{array}{l}+ \\
+\end{array}$ & $\begin{array}{l}+ \\
+\end{array}$ \\
\hline Ornithine decarboxylase & & - & + & - & + \\
\hline Growth at: & $42^{\circ} \mathrm{C}$ & - & - & - & + \\
\hline Acid from: & D-Mannitol & - & + & - & + \\
\hline Production of: & Indol & - & + & - & + \\
\hline Sole carbon source: & D-Mannitol & - & (33) & - & - \\
\hline Resistance to: & $\begin{array}{l}\text { Oxolinic acid }\left(10 \mu \mathrm{g} \mathrm{ml}^{-1}\right) \\
\text { Tetracycline }\left(15 \mu \mathrm{g} \mathrm{ml}^{-1}\right) \\
\text { Trimethoprim }\left(25 \mu \mathrm{g} \mathrm{ml}^{-1}\right)\end{array}$ & $\begin{array}{c}(40) \\
- \\
-\end{array}$ & $\begin{array}{l}- \\
+ \\
+\end{array}$ & $\begin{array}{l}- \\
- \\
-\end{array}$ & $\begin{array}{l}- \\
- \\
-\end{array}$ \\
\hline $\begin{array}{l}\text { a Strains isolated from inte } \\
\text { b Strains isolated from tan } \\
+,-: 100 \% \text { of strains ga }\end{array}$ & $\begin{array}{l}\text { ernal organs of diseased eels } \\
\text { k water and gills of healthy e } \\
\text { ve the indicated result. Numb }\end{array}$ & $\begin{array}{l}\text { during the secono } \\
\text { els. No. of strains } \\
\text { eers in parenthesi }\end{array}$ & $\begin{array}{l}\text { epizootic. No. } \\
\text { indicated in pa } \\
\text { percentage of }\end{array}$ & $\begin{array}{l}\text { ains is indicate } \\
\text { hesis } \\
\text { ive strains }\end{array}$ & d in parenthes \\
\hline
\end{tabular}

during the first outbreak. The eel isolates were also identical to the Japanese strain ATCC 33149, and thus they were identified as biotype 2 strains. The strains recovered from tank water and gills were biochemically similar to the type strain of the species, ATCC 27562, and were therefore identified as $V$. vulnificus biotype 1 strains. The differences between our isolates of biotype 1 and the type strain can be seen in Table 1. Differences were only observed in 3 of the 62 characters tested: $\mathrm{O} / 129$ sensitivity, growth at $42{ }^{\circ} \mathrm{C}$, and growth with mannitol as sole carbon source. The ability to grow at $42^{\circ} \mathrm{C}$ is defined by Tison et al. (1982) as a variable character for biotype 1 strains and as a negative one for biotype 2 strains. On the other hand, the 2 strains from gills were resistant to $O / 129$ and the strain from tank water was able to use D-mannitol as sole carbon source. Resistance to the vibriostatic agent O/129 has previously been reported by Davidson \& Oliver (1986) and Molitoris et al. (1989) for environmental strains of Vibrio species.

The main phenotypic characteristics distinguishing between the 2 biotypes are summarized in Table 1. In the first description of Vibrio vulnificus, biotype 2 and biotype 1 were separated from each other on the basis of 5 of the 68 phenotypic characteristics (Tison et al. 1982): indole production, ornithine decarboxylase, growth at $42^{\circ} \mathrm{C}$, and acid production from mannitol and sorbitol. All of our isolates were negative for acid production from sorbitol and growth at $42^{\circ} \mathrm{C}$; thus, ornithine decarboxylation, indole production, and acid from mannitol constitute the main tests for distinguishing the 2 biotypes.

\section{Drug sensitivity patterns}

Vibrio vulnificus strains of both biotypes exhibited a similar pattern of drug resistance. All strains were resistant to amoxicillin, penicillin $V$, streptomycin, sulfadimethoxine, sulfanilamide, fosfomycin and polymyxin $B$, and were sensitive to ampicillin, carbenicillin, kanamycin, gentamycin, amikacin, tobramycin, erythromycin, chloramphenicol and rifampin. The differences among the studied strains are shown in Table 1 . The environmental strains of biotype 1 were resistant to tetracycline and trimethoprim. Resistance to these antimicrobials has been also described in environmental isolates of other Vibrio species (Amaro et al. 1988), Four eel strains belonging to biotype 2 from the second outbreak were resistant to oxolinic acid, the drug that had been successfully used in the control of the first disease outbreak. The development of resistance to quinolone drugs such as oxolinic acid under selective pressure has been reported by several authors (Cullman et al. 1985). This phenomenon stresses the importance of using methods other than chemotherapy for controlling fish diseases.

\section{Serology}

The agglutination reactions using either whole cells or thermostable somatic ' $\mathrm{O}$ ' antigens of the Vibrio vulnificus strains revealed that all our isolates of biotype 2 from the 2 epizootics were serologically similar 
to the Japanese strain ATCC 33149 (Table 2) The environmental isolates belonging to biotype 1 and the biotype 1 type strain of the species did not agglutinate with the antiserum prepared against the Japanese (biotype 2) strain. This result suggests that surface antigens of the eel isolates are similar, regardless of their geographic origins, and that they are serologically distinct from surface antigens of the isolates of biotype 1. This serological homology in biotype 2 strains had previously been found among isolates from Japanese eels by Nishibuchi \& Muroga (1980) and Tison et al. (1982).

\section{Pathogenicity for eels}

Two Vibrio vulnificus biotype 2 strains, E22 from the first outbreak and E39 from the second one, together with the Japanese (biotype 2) reference strain, were used for virulence assays. The virulence of 1 isolate from tank water (TW1) and the type strain of the species, both of biotype 1, was also investigated to determine if the presence of this biotype in tank water represented a risk for eel culture. The pathogenic assays revealed that $V$. vulnificus biotype 2 was highly virulent for elvers (Table 2) with challenged, moribund fish showing the typical signs of a haemorrhagic septicaemia. The Spanish eel isolates were more virulent $\left(\mathrm{LD}_{50}=<3.2\right.$ to $\left.7.7 \times 10^{2} \mathrm{cfu}\right)$ than the Japanese strain used as the control $\left(1.8 \times 10^{4} \mathrm{cfu}\right)$. $V$. vulnificus strains of biotype 1 proved non-pathogenic for eels (Table 2), which is in accordance with the results obtained by Tison et al. (1982), and suggests that only strains of biotype 2 are eel pathogens. The fact that only biotype 1 strains could be isolated from the water or the surface of eels, whereas biotype 2 strains were only found in the diseased eels of the same tanks, suggests that biotype 2 strains may survive in a viable but nonculturable form in the environment. More studies are needed to test this hypothesis.

\section{Pathogenicity for mice}

Vibrio vulnificus biotype 1 has been described as a human pathogen producing serious wound infections and primary septicaemias (Blake et al. 1980). In immunocompromised patients or those with hepatic disorders, the septicaemia has a reported mortality rate of nearly $60 \%$ (Blake et al. 1980). We investigated both biotypes for their potential pathogenicity to humans using the mouse lethality assay. Results in Table 2 showed that the strains of $V$. vulnificus biotype 2 were more virulent for mice $\left(\operatorname{LD}_{50}=10^{5}\right.$ to $10^{6} \mathrm{cfu}$ ) than the strains of biotype 1 . The biotype 1 type strain ATCC 27562 was weakly virulent for mice $\left(L_{50}=2 \times\right.$ $\left.10^{8} \mathrm{cfu}\right)$, whereas the environmental TW1 isolate was avirulent. In general, experimental mice succumbed within $24 \mathrm{~h}$. The findings indicate that $V$. vulnificus biotype 2 should be regarded as a potential human pathogen and that the presence of this species in the farm environment may constitute a health hazard problem for fish farmers.

\section{Virulence factors}

Bacterial adhesion to appropriate host surfaces is one of the first steps in microbial pathogenesis, thus the adhesion capability to fish and human cell lines of Vibrio vulnificus was tested. $V$. vulnificus biotype 1 did not adhere to RTG-2 cells, whereas strains of biotype 2 were adherent (Table 2). This result is in agreement with the pathogenic potential for fish of strains of bio-

Table 2. Vibrio vulnificus. Origin, serology, virulence for elvers and mice, and adherence to cell monolayers

\begin{tabular}{|c|c|c|c|c|c|c|}
\hline \multirow{2}{*}{$\begin{array}{l}\text { Strain of } \\
\text { V. vuInificus }\end{array}$} & \multirow[t]{2}{*}{ Origin } & \multirow{2}{*}{$\begin{array}{l}\text { Agglutination with rabbit } \\
\text { antisera prepared against } \\
\text { V. vulnificus ATCC } 33149\end{array}$} & \multicolumn{2}{|c|}{ Virulence for ${ }^{2}$} & \multicolumn{2}{|c|}{ Adherence to ${ }^{b}$} \\
\hline & & & Elver & Mouse & RTG-2 & HELA \\
\hline \multicolumn{7}{|l|}{ Biotype 1} \\
\hline $\operatorname{ATCC} 27562$ & Human wound infection & - & - & $+\left(2.0 \times 10^{8}\right)$ & - & + \\
\hline TW1 & Tank water & - & - & - & - & + \\
\hline \multicolumn{7}{|l|}{ Biotype 2} \\
\hline ATCC 33149 & Japanese eel & $+(5120)^{c}$ & $+\left(1.8 \times 10^{4}\right)$ & $+\left(1.0 \times 10^{6}\right)$ & + & + \\
\hline $\mathrm{E} 22$ & European eel, 1st outbreak & $+(5120)$ & $+\left(<3.2 \times 10^{2}\right)$ & $+\left(1.1 \times 10^{5}\right\}$ & + & + \\
\hline E39 & European eel, 2nd outbreak & $+\{5120\}$ & $+\left(<7.7 \times 10^{2}\right)$ & $+\left(5.0 \times 10^{5}\right)$ & + & + \\
\hline
\end{tabular}


Table 3. Enyzmatic, haemolytic, and cytotoxic activities of the Vibrio vulnificus extra-cellular products (ECPs)

\begin{tabular}{|c|c|c|c|c|c|c|c|c|c|c|}
\hline \multirow{2}{*}{$\begin{array}{l}\text { Strain of } \\
\text { V. vulnificus }\end{array}$} & \multirow{2}{*}{$\begin{array}{l}\text { Protein } \\
\text { content } \\
\text { of } \mathrm{ECP} \\
\left(\mu \mathrm{gl}^{-1}\right)\end{array}$} & \multicolumn{4}{|c|}{ Production of ${ }^{t}$} & \multirow{2}{*}{$\begin{array}{l}\text { Hemolysin } \\
\text { production }^{\circ}\end{array}$} & \multicolumn{4}{|c|}{ Cytotoxic response on } \\
\hline & & Gel & Cas & Lip & Phos & & $\begin{array}{c}\text { CHSE- } \\
214\end{array}$ & $\begin{array}{l}\text { RTG- } \\
2\end{array}$ & EPC & HELA \\
\hline \multicolumn{11}{|l|}{ Biotype 1} \\
\hline ATCC 27562 & 1024 & $+(1.7)$ & $+(1.6)$ & - & - & $+(0.7)$ & + & + & $+(1.4)$ & + \\
\hline TW1 & 822 & $+(1.7)$ & $+\{1.2\}$ & - & - & $+(0.8)$ & + & + & $+(1.1)$ & + \\
\hline \multicolumn{11}{|l|}{ Biotype 2} \\
\hline ATCC 33149 & 1476 & $+(1.4)$ & $+(1.0)$ & $+(0.5)$ & $+(0.6)$ & $+(0.7)$ & + & + & $+(1.0)$ & + \\
\hline $\mathrm{E} 22$ & 1868 & $+(2.2)$ & $+(1.2)$ & - & - & - & + & + & $+(0.9)$ & + \\
\hline E39 & 1870 & $+(2.0)$ & $+(1.2)$ & - & - & - & + & + & $+(1.2)$ & + \\
\hline \multicolumn{11}{|c|}{$\begin{array}{l}\text { "Gel: gelatinase; Cas: caseinase; Lip: lipase; Phos: phospholipase. Diameter of the hydrolysis halo (in } \mathrm{cm} \text { ) is indicated in } \\
\text { parenthesis } \\
\text { b Haemolysins against sheep erythrocytes. Diameter (in } \mathrm{cm} \text { ) of haemolysis zone is indicated in parenthesis } \\
\text { 'Data in parenthesis showed the minimal protein dose }\left(\mu \mathrm{g} \mathrm{ml}^{-1} \text { ) that produced cytotoxic response on EPC cell line }\right. \\
\text { +: rounding and total cell detachment within } 3 \mathrm{~h}\end{array}$} \\
\hline
\end{tabular}

type 2 (Table 2). On the other hand, both biotype adhered to HELA cells, a result that accorded fairly well with the results of the mouse bioassay which was intended to reveal the potential of the biotypes as human pathogens.

Production of toxic extracellular products such as proteases, lipases, phospholipases, haemolysins, and cytotoxins has been investigated mainly in relation to virulence of Vibrio vulnificus biotype 1 for humans (Kreger \& Lockwood 1981, Oliver et al. 1986, Kaysner et al. 1987). The pathogenicity mechanisms of strains of biotype 2 to eels are unclear, but probably involve toxins (enzymes) (Austin \& Austin 1987). Assays showed strains of both biotypes to be strongly cytotoxic, their toxins resulting in total destruction of fish and human cell monolayers at supernatant dilutions as high as 1:750 for biotype 1, and 1:1500 for biotype 2. However, the minimal protein dose needed to produce cytopathic effects was similar for both biotypes (Table 3). Toxic effects were always observed within $3 \mathrm{~h}$ of incubation and were manifested by rounding, shrinking, dendritic elongation, and finally, cell detachment (Fig. 1). Trypan-blue staining revealed that approximately $80 \%$ of fish and human cells remained viable after total detachment from the monolayer. The heating of all extracellular products at $80^{\circ} \mathrm{C}$ for $15 \mathrm{~min}$ produced a loss of their cytotoxic effects, indicating the thermolabile nature of the toxins.

The enzymatic activities of the ECPs were also evaluated (Table 3). Some differences were found among the hydrolytic profiles exhibited by the ECPs of strains of biotype 2 . The only appreciable enzymatic activity in the ECPs of European eel isolates was the proteo- lytic activity against gelatin and casein. Interestingly, the ECP of the Japanese strain also showed lipase and phospholipase activities and produced haemolysis of sheep erythrocytes (Table 3). The ECPs of the strains of biotype 1 were proteolytic and haemolytic.

Finally, we conclude that the strains of Vibrio vulnificus biotype 2 , serologically identical to the original Japanese isolates, were the agents responsible for the 2 disease outbreaks that occurred at the eel farm located near Valencia. These strains shared a number of features in common with the biotype 1 strains, including the ability to produce cytotoxins and proteases. They differed from the biotype 1 strains, however, in their serology and in their ability to adhere to fish cells - features that might help to account for their pathogenicity to eels. Firm conclusions on this are not yet warranted but, on the basis of the Japanese and our results on the biotype 2 strains, it seems clear that we are dealing with a serologically distinct group of strains within the species $V$. vulnificus and that this group represents an eel pathogen.

Acknowledgements. This work was partially supported by grants MAR91-1206 and MAR91-1133-C02-01 from the Comisión Interministerial de Ciencia y Tecnología (CICYT) of Spain. C. Amaro, C. Esteve and E. C. Biosca thank the Consellería de Cultura, Educación y Ciencia de la Generalitat Valenciana and B. Fouz thanks the Consellería de Educación de la Xunta de Galicia for their research fellowships. The authors thank M. Ortigosa for providing the environmental isolates and R. Ruano (Consellería de Agricultura y Pesca de la Generalitat de Valenciana) for supplying the elvers for the virulence assays. 


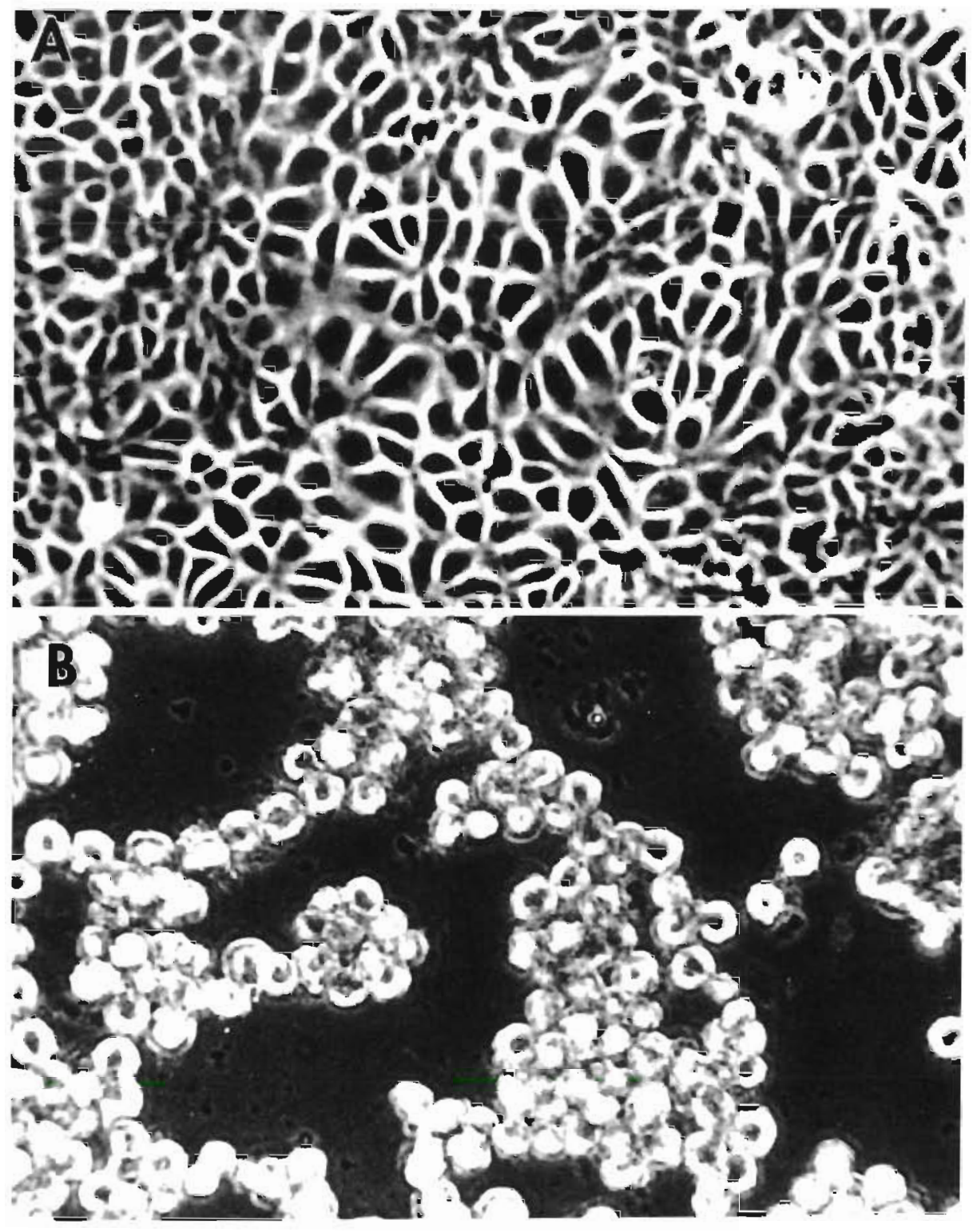

Fig. 1. Cytotoxic effect of the extracellular products (ECP) of strain E22 Vibrio vulnuficus biotype 2 on CHSE-214 cells. (A) Control cell monolayer inoculated with sterile broth. (B) Cytotoxic effect of the ECP manifested by total rounding and cell detachment within 3 h of incubation

\section{LITERATURE CITED}

Amaro, C.. Aznar, R., Garay, E., Alcaide, E. (1988\}. R-plasmids in environmental Vibrio cholerae non-O1 strains. Appl. environ. Microbiol. 54: 2771-2776

Austin, B., Austin, D. A. (1987). Bacterial fish pathogens disease in farmed and wild fish. Ellis Horwood, Chichester Biosca, E. G., Amaro, C., Esteve, C., Alcaide, E., Garay, E. (1991). First report of Vibno vulnificus biotype 2 isolated from European eel (Anguilla anguilla). J. Fish. Dis. 14: $103-109$

Blake, P. A., Weaver, R. E., Hollıs. D. G. (1980). Disease of humans (other than Cholera) caused by vibrios. Ann. Rev Microbiol. 34: 341-367
Bradford, M. M. (1976). A rapid and sensitive method for the quantitation of morogram quantities of protein utilizing the principle of protein-dye binding. Anal. Biochem. 72 : $248-254$

Cullman, W., Stieglitz, M., Baars, B., Opferkuh, W. (1985) Comparative evaluation of recently developed quinolone compound with a note of the frequency of resistant mutants. Chemotherapy 31. 19-28

Davidson, L., Oliver, J. D. (1986). Plasmid carriage in Vjbrio vulnificus and other lactose-fermentung marine vibrios. Appl. environ. Microbiol. 51: 211-213

Kaysner, C. A., Abeyta, C., Wekell, M. M., DePaola, A., Stott. R. F., Leicht, J. M. (1987). Virulent strains of Vibrio vul nificus isolated from estuaries of the United States west 
coast. Appl. environ. Microbiol. 53: 1349-1351

Kelly, M. T (1982). Effect of temperature and salinity of Vibrio (Beneckea) vulnificus occurrence in Gulf Coastal estuaries. Appl environ. Microbiol. 44: 820-824

Kreger, A., Lockwood, D. (1981). Detection of extracellular toxin(s) produced by Vibrio vulnificus. Infect. Immun. 33: $583-590$

Liu, P. V (1957). Survey of haemolysin production among species of pseudomonads. J. Bacteriol. 74: 718-727

Molitoris, E., Marii, M. A., Joseph, S. W., Krochevsky, M. I., Fanning, F. R., Last. G., El-Mishad, A. M. El Batawi, Y. A., Colwell, R. R. (1989). Numerical taxonomy and deoxyribonucleic acid relatedness of environmental and clinical Vibrio species isolated in Indonesia. Int. J. Dyst. Bacteriol. 39: $442-449$

Muroga, K., Jo, Y., Nishibuchi, M. (1976a). Pathogenic Vibrio isolated from cultured eels. I. Characteristics and taxonomic status. Fish Pathol. 11: 141-145

Muroga, K., Nishibuchi, M., Jo, Y (1976b). Pathogenic Vibrio isolated from cultured eels. II. Physiological characteristics and pathogenicity. Fish Pathol. 11: 147-151

Nisibuchi, M., Muroga, K. (1980). Pathogenic Vibrio isolated from cultured eels. $V$. Serological studies. Fish Pathol. 14: $117-124$

Responsible Subject Editor: T. Evelyn, Nanaimo, B.C.. Canada
Oliver, J. D., Wear, J. E., Thomas, M. B., Warner, M. P., Linder, K. (1986). Production of extracellular enzymes and cytotoxicity by Vibroo vulnificus. Diagn. Microbiol. Infect. Dis. 5: $99-111$

Reed, M. J., Muench, H. (1938). A simple method for estimating fifty percent endpoints. Am. J. Hyg. 27: 493-497

Santos, Y.. Bandin, I., Nieto, T P., Bruno, D. W., Ellis, A. E., Toranzo, A. E. (1990). Comparison of the cell surface hydrophobicity of bacterial fish pathogens. In: Pathology in marine sciences. Academic Press, London, p. 101-115

Tison, D. L., Nishibuchi, M., Greenwood, J. D., Seidler, R. J. (1982). Vibrio vulnificus biogroup 2: new biogroup pathogenic for eels. Appl. environ. Microbiol. 44:640-646

Toranzo, A. E., Barja, J. L., Colwell, R. R., Hetrick, F. M., Crosa, J. H. (1983). Haemagglutinating, haemolytic and cytotoxic activities of Vibrio anguillarum and related vibrios isolated from striped bass on the Atlantic coast FEMS Microbiol. Lett. 18: 257-262

Toranzo, A. E., Baya, A. M., Roberson, B. S., Barja, J. L., Grimes, D. J. (1987). Specificity of slide agglutination test for detecting bacterial fish pathogens. Aquaculture 61: 81-97

Wright, A. C., Simpson, L. M., Oliver, J. D., Morris, J. G. (1990). Phenotypic evaluation of acapsular transposon mutants of Vibrio vulnificus. Infect. Immun. 58: 1769-1773

Manuscript first received: March 8, 1991

Revised version accepted: January 14, 1992 